\title{
The Role of Communication Strategies in the Classroom Communication
}

\author{
Yuni Asih Trihastuti \\ Applied Linguistic Study Department \\ Yogyakarta State University \\ Yogyakarta, Indonesia \\ yuniasih.trihastuti129@gmail.com
}

\author{
Zamzani \\ Indonesian Language Education Study Program \\ Yogyakarta State University \\ Yogyakarta, Indonesia \\ zamzani@uny.ac.id
}

\begin{abstract}
Communication happened in every time, situation, and places including school. School is a place where student built their connectivity and interaction with another student and also teachers. During teaching and learning process, knowledge is transferred from teacher to students. Good communication is needed to make sure that everything running well. This article examines the role of communication strategies in classroom communication based on the theoretical background that has been declared by researchers. The method of this research is qualitative descriptive with literature review design, the writer use the design to get reliable information about communication strategies. Classroom communication aims to share information and to create the same point of view among the teacher and students. The effective classroom communication will bring successful teaching and learning process. However, to achieve that, both teacher and students may have some difficulties. There are some types of Communication strategies that may be used by teacher and students. Most of the use of communication strategies could be a problem solver such as approximation, literal translation, and code-switching which belong to Compensatory Strategy that could be used for clarifying meaning. In the other side, Communication Strategies could be another problem made by communicators, for instance, the use of topic avoidance and message abandonment may come to mind a miss-conception in teaching and learning process. In what way the role of communication strategies in the classroom will be enlightened more in the article.
\end{abstract}

Keywords-communication

strategies;

classroom communication

\section{INTRODUCTION}

During teaching and learning process, communication happens to transfer the knowledge between teacher and students. The communication process in the classroom also known as a classroom communication is a way to create an effective teaching and learning process. Classroom Communication happens for a reason. It happens in the class between teacher and student, teacher and a group of students, and of course student to student.

The interaction that occurs in the classroom give an impact for teaching and learning process, it can be a medium to improving students communication skill, or that may be used for the teacher to make a good atmosphere in the class. Fojkar [1] explain that communication in classroom situation also has a purpose like other communication, in classroom people gather for learning, here teacher trying to make a good personal relationship between teacher and student, the teacher has to establish a rapport with the class, with its individuals, and individual students from different sorts of relationships with the group and with the teacher.

The importance of communication in the classroom also stated by Barker [2] he argues that classroom communication is one of the most important communication forms occurring in society, through oral interaction in the classroom, students and teacher could develop their personality, intellectual and sociality.

\section{COMmunication STRATEGIES}

The study of communication strategy (CS) was conducted by some researchers emerging some definition of CS. Starting with Tarone in 1979 which defining communication strategy as one of the strategies in language use, She stated that communication strategy is a mutual attempt use by two interlocutors to agree on a meaning in a situation where requisite meaning structures do not seem to be shared (meaning structures include both linguistic and sociolinguistic features) [3]. In Tarone's taxonomy, CS is classified into three major categories namely: paraphrase, borrowing, and avoidance, besides that Tarone, also completing the categories by adding appeal for assistance and mime. Meanwhile, Faerch and Kasper [4] defining CS from a psycholinguistic perspective as a strategy related to individual language users' experience of communicative problems and the solutions whether that is cooperative or non-cooperative. They also classified CS into three categories they are the formal reduction, functional reduction, and achievement strategies or called as compensatory strategies. Each type has detailed information as follows: 
TABLE I. COMMUNICATION STRATEGIES DEFINED BY [4]

\begin{tabular}{|l|l|l|l|}
\hline No & Formal Reduction & \multicolumn{1}{|c|}{$\begin{array}{c}\text { Functional } \\
\text { Reduction }\end{array}$} & \multicolumn{1}{|c|}{$\begin{array}{c}\text { Compensatory } \\
\text { Strategies }\end{array}$} \\
\hline 1 & phonological & topic avoidance & code switching \\
\hline 2 & morphological & $\begin{array}{l}\text { message } \\
\text { abandonment }\end{array}$ & interlingual transfer \\
\hline 3 & syntactic & meaning replacement & generalization \\
\hline 4 & lexical & & paraphrase \\
\hline 5 & & & word coinage \\
\hline 6 & & & restructuring \\
\hline 7 & & & cooperative strategies \\
\hline 8 & & & $\begin{array}{l}\text { Non-linguistic } \\
\text { strategies }\end{array}$ \\
\hline
\end{tabular}

Although both researchers have different perspective in defining communication strategies there are several similarities on the components of communication strategies between them. Another studies conducted by Dornyei also creating similar components of communication strategies. According to Dornyei people with lack of vocabularies can communicate effectively in the target language by using their hands, imitating the sound or movement of things, mixing languages, they create new words, they describe circumlocution something they don't know the word for - in short, they use communication strategies. He compare two concepts of communication strategies, the first from tradional and other from Nijmegan university Group.

TABLE II. CSS FOLLOWING TRADITIONAL CONCEPTUALIZATION

\begin{tabular}{|c|c|}
\hline \multicolumn{2}{|r|}{ Avoidence Strategies } \\
\hline $\begin{array}{l}1 . \\
2 .\end{array}$ & $\begin{array}{l}\text { Message abandonment: Leaving a message unfinished because of } \\
\text { language difficulties. } \\
\text { Topic avoidance: Avoiding topic areas or concepts that pose } \\
\text { language difficulties. }\end{array}$ \\
\hline \multicolumn{2}{|r|}{ Compnsatory Strategies } \\
\hline $\begin{array}{l}3 . \\
4 .\end{array}$ & $\begin{array}{l}\text { Circumlocution: Describing or exemplifying the target object of } \\
\text { action (e.g. the thing you open wine bottles with for corkscrew). } \\
\text { Approximation: Using an alternative term which expresses the } \\
\text { meaning of the target lexical item as closely as possible (e.g. ship } \\
\text { for sailboat). }\end{array}$ \\
\hline 5. & $\begin{array}{l}\text { Use of all-purpose words: Extending a general, empty lexical } \\
\text { item to contexts where specific words are lacking (e.g. the } \\
\text { overuse of thing, stuff, what-do-you call-it, thingy). }\end{array}$ \\
\hline & $\begin{array}{l}\text { Word coinage: Creating a nonexistent second language (L2) } \\
\text { word based on a supposed rule (e.g. vegetarianist for vegetarian). }\end{array}$ \\
\hline 7. & $\begin{array}{l}\text { Prefabricated patterns: Using memorized stock phrases, usually } \\
\text { for "survival" purposes (e.g. Where is the _ ? Or Comment } \\
\text { allez vous? where the morphological components are not known } \\
\text { to the learner). }\end{array}$ \\
\hline 8. & $\begin{array}{l}\text { Nonlinguistic signals: Mime, gesture, facial expression, or sound } \\
\text { imitation. }\end{array}$ \\
\hline 9. & $\begin{array}{l}\text { Literal translation: Literally translating a lexical item, idiom, } \\
\text { compound word, or structure from the native language (L1) to } \\
\text { L2. }\end{array}$ \\
\hline & $\begin{array}{l}\text { Foreignizing: Using an L1 word by adjusting it to the L2 } \\
\text { phonology (i.e. with an L2 pronunciation) and/or morphology } \\
\text { (e.g. adding an L2 suffix to it). }\end{array}$ \\
\hline & $\begin{array}{l}\text { Code-switching: Using an L1 word with L1 pronunciation or an } \\
\text { L3 word with L3 pronunciation while speaking in L2. }\end{array}$ \\
\hline & $\begin{array}{l}\text { Appealing for help: Asking for aid from the interlocutor either } \\
\text { directly (e.g. What do you call...?) or indirectly (e.g. rising } \\
\text { intonation, pause, eye contact, puzzled expression). }\end{array}$ \\
\hline 13. & $\begin{array}{l}\text { Stalling or time-gaining strategies: Using fillers or hesitation } \\
\text { devices to fill pauses and to gain time to think (e.g. well, now, } \\
\text { let's see, uh, as a matter of fact). }\end{array}$ \\
\hline
\end{tabular}

\section{THE ROLE OF COMMUNICATION STRATEGIES}

In teaching English as a foreign language the teacher should be using English for communicating and delivering the material. The use of English is an effort that could make English familiar to students. Indonesian students who speak more than one language sometimes got some problems in speaking or communicating by using English. To solve the problem they must look for a way to communicating and to make the interlocutors understand what they said. The use of meme, gesture, or sometimes mixing and switching code, are some attempts to keep the communication running well. The use of communication strategy during classroom communication has an important role. Canal and Swain stated that Oral communication strategies were defined as: 'verbal and non-verbal communication strategies that may be called into action to compensate for breakdowns in communication due to performance variables or to insufficient competence'. Varadi asserted that CSs were seen as language devices used to overcome communication problems related to the interlanguage deficiencies. Bialystok [5] noted that the main CS- defining criterion which has been widely employed is the problematicity; thus, the widely accepted definition containing problem - orientedness as "only when a speaker perceives that there is a problem which may interrupt communication".

Keeping the communication in the class running smothly also became a role of CS, as asserted by Dornyei that the use of stalling strategies such as lexicalized pause-filler, and hesitation gambits, helps spekers gain time to think and keep the communication chanel open.

Another study found that communication strategies has three features, (1) problematic, it reffers to the fact that learners use CSs as they encounters communication problem. (2) Conciusnes, it is a potentially concious plan for solving communication problem to reach a particular communicative goal. It also refers either to the students' awarness that the strategy is being employed for a particular purpose, or the awerness of how the strategy might achieves it intended effect. (3) intentionality, refers to the learner's control over those strategies so that particular ones may be selected from the range of options and deliberately applied to achieve certain effects. [6].

\section{CONCLUSION}

In EFL classroom that use target language student and teacher may faced communication problem. Based on the explanaition above it could be stated that communication strategies (CSs) has an important role in classroom communication. CS helps students and also teacher in communicating, the use of switch code for example could helps students who has lack proficiency to explain what they mean. 


\section{ACKNOWLEDGMENT}

The writers would like to thank to everyone who support and helped in the making of this article. Without them this article will not complete well.

\section{REFERENCES}

[1] M. D. Fojkar, "Classroom Interaction and Communication Strategies in Learning English as a Foreign Language,” English Lang. and Lit. Teach., pp. 127-139, August 2016.

[2] L. L. Barker, Communication in the Classroom. Englewood Cliff: Prentice-Hall, Inc. 1982.

[3] E. Tarone, "Communication Strategies, Foreigner Talk, and Repair in Interlanguage Studies,” Lang. Learn., 30, vol. 30, no. 2, pp. 417-431, 1980.

[4] C. Faerch and G. Kasper, "Two Ways of Defining Communication: Claw Fmch University of Copenhagen Gabriele Kasper University of Aarhus,” Lang. Learn., vol. 34, no. 1, pp. 45-63, 1983.

[5] E. Bialystok, Communication strategies. Oxford: Blackwell. 1990.

[6] M. Sukirlan, Communication Strategies and Their Linguistic Features. Yogyakarta: Graha Ilmu. 2017. 